\title{
Allelopathic Activity of Extracts from Different Brazilian Peanut (Arachis hypogaea L.) Cultivars on Lettuce (Lactuca sativa) and Weed Plants
}

\author{
G. S. Casimiro, ${ }^{1}$ E. Mansur, ${ }^{1}$ G. Pacheco, ${ }^{1}$ R. Garcia, ${ }^{1}$ I. C. R. Leal, ${ }^{2}$ and N. K. Simas ${ }^{2}$ \\ ${ }^{1}$ Laboratory of Micropropagation and Plant Transformation, Cellular Biology Department, State University of Rio de Janeiro, \\ Rio de Janeiro, RJ, Brazil \\ ${ }^{2}$ Laboratory of Natural Products and Biological Assays, Department of Natural Products and Food, School of Pharmacy, \\ Federal University of Rio de Janeiro, Rio de Janeiro, RJ, Brazil
}

Correspondence should be addressed to G. S. Casimiro; gclss@globo.com

Received 5 September 2016; Revised 20 December 2016; Accepted 19 January 2017; Published 15 March 2017

Academic Editor: Paula B. Andrade

Copyright (C) 2017 G. S. Casimiro et al. This is an open access article distributed under the Creative Commons Attribution License, which permits unrestricted use, distribution, and reproduction in any medium, provided the original work is properly cited.

Peanut (Arachis hypogaea L.) is the fourth most consumed oleaginous plant in the world, producing seeds with high contents of lipids, proteins, vitamins, and carbohydrates. Biological activities of different extracts of this species have already been evaluated by many researchers, including antioxidant, antitumoral, and antibacterial. In this work, the allelopathic activity of extracts from different Brazilian peanut cultivars against lettuce (Lactuca sativa) and two weed plants (Commelina benghalensis and Ipomoea nil) was studied. Aerial parts, roots, seeds, and seed coats were used for the preparation of crude extracts. Seed extract partitioning was performed with $n$-hexane, dichloromethane, ethyl acetate, $n$-butanol, and aqueous residue. Germination and growth of hypocotyls and rootlets were evaluated after one and five days of incubation with plant extracts, respectively. Crude seed extract and its dichloromethanic partition displayed highest allelopathic activity. These results contribute for the study of new potential natural herbicides.

\section{Introduction}

Peanut (Arachis hypogaea L., Leguminosae) is the fourth most planted and consumed oilseed worldwide and also a good option for crop rotation. In addition to its flavour, peanut seeds have a high content of lipids (about $50 \%$ ), proteins $(22 \%$ to $30 \%$ ), mineral salts, vitamins, and carbohydrates, being highly energetic, with an average of 585 calories per 100 grams of the grain [1].

The evaluation of different biological activities within the genus Arachis led to the recognition of antioxidant, antibacterial, antitumoral, and anti-inflammatory potentials, among others. However, allelopathic activity is comparatively less investigated. Allelopathy is any positive or negative effect of one plant on another through the production of chemicals that are released into the environment [2]. A great importance of plants with allelopathic activity is to fight against weed plants, which are defined as plants that grow where they are not desired, along with agricultural crops, interfering in their development and reducing productivity [3]. Although routinely weed plants are combated with herbicides, their indiscriminate use leads to the development of resistant plants. In addition, the impact of herbicides on human health is also another debatable fact. In this context, the search for natural products instead of synthetic herbicides for weed plant management is highly recommended $[4,5]$.

To our knowledge, the allelopathic potential has already been studied only in two species of genus Arachis. The inhibitory activity of seed extracts in the germination of millet and the effect of root and leaf extracts of A. hypogaea on rice, maize, radish, and rye grass, besides a positive stimulus of aqueous extracts of $A$. pintoi on the germination of tomato seeds (Solanum lycopersicum) and pepper (Capsicum annum), have been studied [6-8]. 
In view of this fact, this paper evaluates the allelopathic activity of extracts from different organs of five Brazilian peanut (Arachis hypogaea L.) cultivars against lettuce (Lactuca sativa) and weed plants (Commelina benghalensis and Ipomoea nil).

\section{Material and Methods}

2.1. Plant Material. Aerial parts, roots, seeds, and seed coats of five Brazilian peanut cultivars, named IAC 886 (Virginia Runner), IAC Caiapó (Virginia Runner), IAC Tatu ST (Valencia), IAC 8112 (Spanish), and IAC BR-1 (Valencia), were used in this study. Plants were grown from seeds in the greenhouse of Rio de Janeiro State University, Brazil, in pots containing Plantmax ${ }^{\circledR}$. Light intensity in a clear day during the growing period was as high as $1600 \mu \mathrm{E} /\left(\mathrm{m}^{2} / \mathrm{s}\right)$. Aerial parts and roots were taken for extraction 30 days after planting.

\subsection{Preparation of Extracts}

2.2.1. Crude Extracts. Plant materials were dried in an oven at $50^{\circ} \mathrm{C}$, crushed, and weighed. Soaking in ethanol $100 \%$ was preceded by a degreasing step with $n$-hexane (five stages during ten days). Maceration in ethanol was performed in the dark at room temperature (five stages during ten days). After filtration on filter paper and concentration in a vacuum rotary evaporator at $45^{\circ} \mathrm{C}$, extracts were weighed and stored at $4{ }^{\circ} \mathrm{C}$ until used.

2.2.2. Partitioned Extracts. The extract of cultivar BR-1 seeds was resuspended in methanol: distilled water $(9: 1)$ and subjected to successive liquid-liquid partitioning using organic solvents of increasing polarity, namely, $n$-hexane, dichloromethane, ethyl acetate, and $n$-butanol, followed by concentration in a vacuum rotary evaporator at $45^{\circ} \mathrm{C}$.

\subsection{Evaluation of Allelopathic Activity}

2.3.1. Germination of Seeds. Samples of the extracts were dissolved in chloroform and the volume adjusted to the desired concentrations (1000, 500, 200, and 100 ppm). Each petri dish $(d=6 \mathrm{~cm}, h=1 \mathrm{~cm})$ containing filter paper discs Whatman ${ }^{\circledR}$ No. $1(d=5.7 \mathrm{~cm})$ received $0.5 \mathrm{~mL}$ of the extract. After solvent evaporation at room temperature (24 hours), ten seeds (L. sativa, C. benghalensis, or I. nil) and $2.5 \mathrm{~mL}$ of distilled water with DMSO $0.1 \%$ were added to the petri dish. All assays were conducted in triplicate, with three replications. Menadione in the concentration of 200 ppm served as positive control, while distilled water with DMSO $0.1 \%$ was used as negative control. Experiments were conducted in a growth chamber in the dark, at $25 \pm 2^{\circ} \mathrm{C}$. The evaluation of germination was performed $24 \mathrm{~h}$ after the introduction of seeds. The criterion for germination reading was the rootlet protrusion. The percentages of germination inhibition were calculated by comparison with the untreated control, using the following calculation: \% inhibition $=(C-$ $X) / C \times 100$, where $C$ is the number of seeds germinated in control and $X$ is the number of seeds germinated in the test sample.
TABLE 1: Inhibition of L. sativa seeds germination by crude ethanolic extracts of aerial part, root, seed coat, and seed of BR-1 cultivar from Arachis hypogaea.

\begin{tabular}{lc}
\hline Crude extract (BR-1-1000 ppm) & Inhibition of germination (\%) \\
\hline Aerial part & $24.44^{\mathrm{c}}$ \\
Root & $35.46^{\mathrm{b}}$ \\
Seed coat & $47.78^{\mathrm{a}}$ \\
Seed & $47.78^{\mathrm{a}}$ \\
\hline
\end{tabular}

The same letter means no statistically significant difference between the samples.

2.3.2. Hypocotyls and Rootlets Growth. Seedling growth was evaluated five days after the introduction of the seeds with opening of plates. The percentages of inhibition were calculated by comparison with the untreated control, using the following formula: \% inhibition $=(C-X) / C \times 100$, where $C$ is the average size of hypocotyl/rootlet in control and $X$ is the average size of the hypocotyl/rootlet in the test sample $[9,10]$.

2.4. Statistical Analysis. Statistical evaluation of experimental data was performed by analysis of variance (ANOVA) and Tukey's comparison test, with the aid of the Graphpad Prism $5^{\circledR}$. The value of $p \leq 0.05$ was considered significant, and a confidence interval of $95 \%$ was adopted.

\section{Results}

3.1. Evaluation of Crude Ethanolic Extracts. The effect of crude extracts from cultivar BR-1 (aerial part, root, seed, and seed coat) was evaluated on the germination and growth of hypocotyls and rootlets of $L$. sativa. Seed and seed coat extracts showed highest percentages of inhibition of germination $(47.78 \%)$, when compared to root $(35.46 \%)$ and aerial part extracts (24.44\%) (Table 1$)$.

On the other hand, aerial part extract caused the highest percentages of growth inhibition in rootlets, when compared with hypocotyls. Similarly, root and seed extracts reached the higher percentage of inhibition on rootlets growth. Nevertheless, the percentage of inhibition induced by root extracts on the hypocotyls was higher when compared with the inhibition showed by extracts of aerial parts. Unlike these materials, seed coat extracts promoted greater inhibition on hypocotyls, when compared with rootlets, while the inhibition on rootlets was similar to those of the other extracts tested (Figure 1).

The $\mathrm{IC}_{50}$ (concentration of extract required to inhibit $50 \%$ of Lactuca sativa growth) was used for comparison of the activity of the different extracts from cultivar BR1. Seed extracts showed the lowest $\mathrm{IC}_{50}$ values $(72.98 \mathrm{ppm}$ for hypocotyl and $77.43 \mathrm{ppm}$ for rootlet development), while the root extract showed the highest values $(367.5 \mathrm{ppm}$ for hypocotyl and 472.5 for rootlet). The aerial part and seed coat extracts displayed similar values (91.46 ppm to $106.1 \mathrm{ppm}$ ) (Table 2).

The concentration corresponding to the lower $\mathrm{IC}_{50}$ values, obtained with cultivar BR-1 in order to inhibit the development of hypocotyls or rootlets, was used for the 
(I) Average growth of hypocotyls
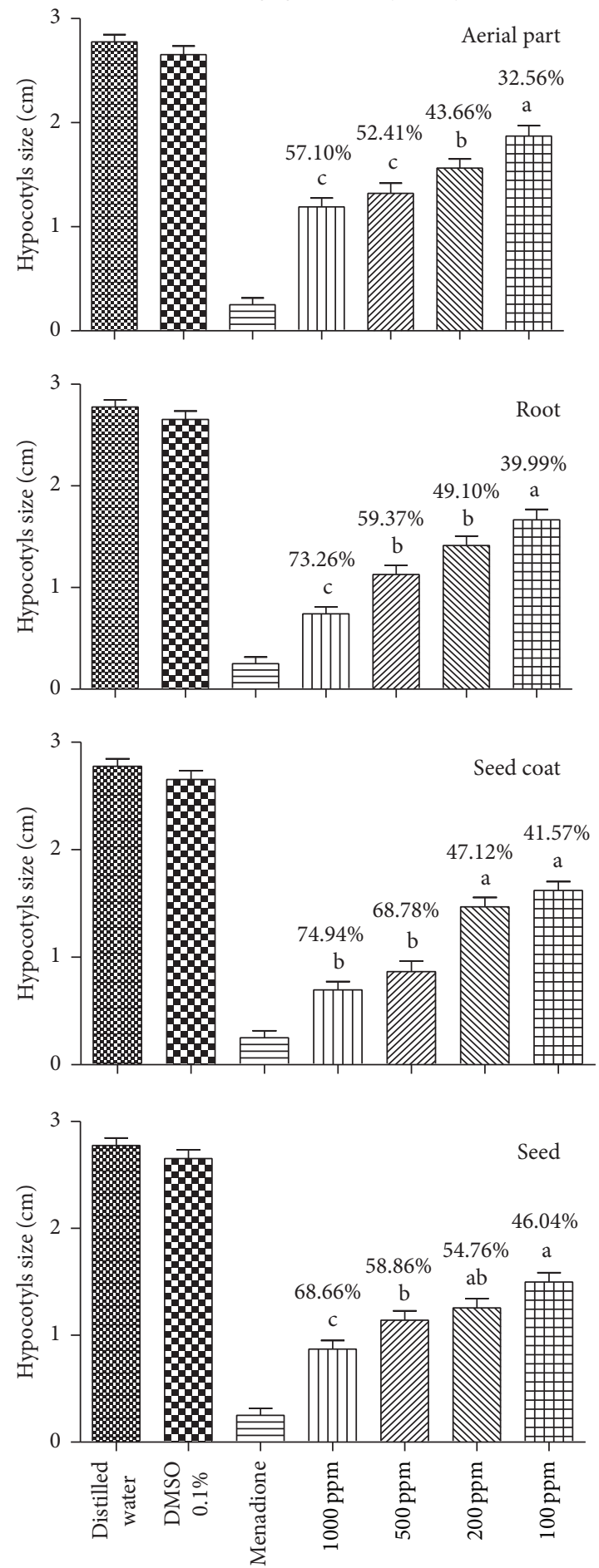

(II) Average growth of rootlets
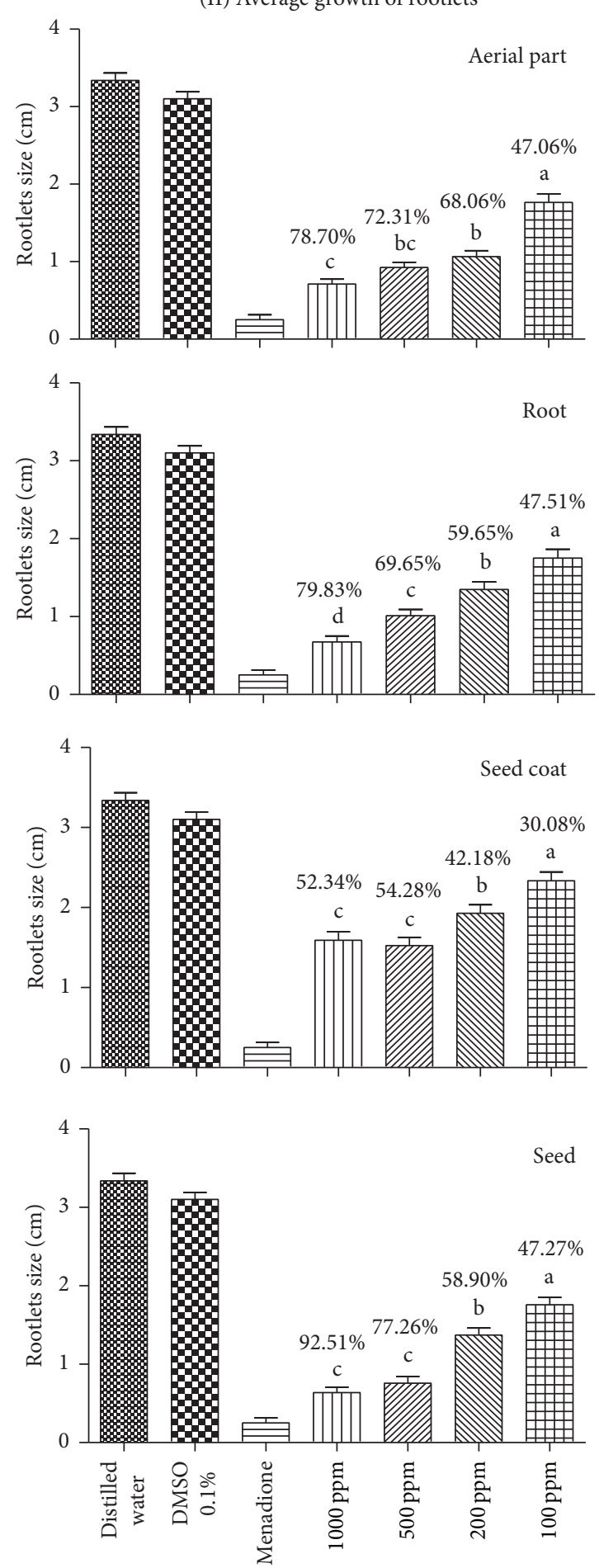

FIGURE 1: Evaluation of allelopathic activity of ethanolic extracts of Arachis hypogaea (cultivar BR-1) on the growth of hypocotyls and rootlets of L. sativa based on the average lengths of each organ and the inhibition percentages relative to distilled water control. The same letter means no statistically significant difference between the samples in each graphic, according to Tukey's test. 
TABLE 2: $\mathrm{IC}_{50}$ of crude ethanolic extracts of cultivar BR-1 of $A$. hypogaea on the inhibition of L. sativa growth of hypocotyls and rootlets.

\begin{tabular}{lcc}
\hline Crude ethanolic extract & \multicolumn{2}{c}{$\mathrm{IC}_{50}(\mathrm{ppm})$} \\
\hline Aerial part & Hypocotyl & Rootlet \\
Root & 36.91 & 96.68 \\
Seed coat & 106.1 & 472.5 \\
Seed & 72.98 & 91.46 \\
\hline
\end{tabular}

comparative analysis of extracts from other cultivars. The highest inhibition percentages $(52.87 \%$ for hypocotyl and $58.25 \%$ for rootlet) were obtained with extracts from the aerial part of cultivar IAC 886 (Table 3).

3.2. Evaluation of Partitioned Extracts. The allelopathic activity of liquid-liquid partitions of the ethanolic extract of seeds of BR-1 ( $n$-hexane, dichloromethane, ethyl acetate, $n$ butanol, and aqueous residue) was also evaluated. The inhibition caused by the nonpolar partitions, dichloromethanic (68.89\%) and hexanic (57.78\%), was much higher than that attained with the other partitions tested (13.33 to $16.67 \%$ ) (Table 4).

The inhibition percentages of growth of rootlets and hypocotyls varied according to the partition. The values obtained with the hexanic partition $(80.79 \%$ for hypocotyl and $84.02 \%$ for rootlets at $1000 \mathrm{ppm}$ ) were higher than those achieved with the crude extract, which showed an inhibition of $68.66 \%$ on the growth of hypocotyls. Percentages found for rootlets were lower than those showed by the crude extract (until $92.51 \%$ at $1000 \mathrm{ppm}$ ). The dichloromethanic partition also caused the highest percentages of inhibition of growth of hypocotyls and rootlets (90.27 and 92.21, respectively, at $1000 \mathrm{ppm})$. Growth inhibition rates of ethyl acetate partition reached similar percentages when compared to crude extract. Butanolic partition and aqueous residue had the lowest percentages of inhibition, both in relation to other partitions and as compared to crude extracts (Figure 2).

As expected, the lowest value for $\mathrm{IC}_{50}$ was found with dichloromethanic partition on rootlets (19.70 ppm), while the highest value was found for aqueous residue (1360.0 ppm). All partitions evaluated, except dichloromethanic, showed lower $\mathrm{IC}_{50}$ values for hypocotyls as compared to rootlets growth (Table 5).

The dichloromethanic partition at $\mathrm{IC}_{50}(19.70 \mathrm{ppm})$ was evaluated for allelopathic activity on two weed species that affect Arachis hypogaea crops, Commelina benghalensis and Ipomoea nil. Although the inhibition of seed growth on $I$. nil was greater than on C. benghalensis, the inhibition of both species was lower than the observed in L. sativa (Table 6).

\section{Discussion}

In the present study, evaluations of allelopathic activity were made with ethanolic extracts of different materials as well as with liquid-liquid partitions of seed extracts from five cultivars of $A$. hypogaea. The allelopathic activity of peanut extracts has also been previously studied by other workers. Similar results to those obtained here were reported when the activity of aqueous extracts of different organs (root, stem, leaf, and flower) on the inhibition of germination of cucumber seeds was analyzed [11]. However, while these authors found highest allelopathic activity in root extracts, we attained best effects with ethanolic seed extracts. This difference shows that allelopathic activity of different organs of the same plant can vary according to the method used and the target species.

Inhibition of germination is one of the most parameters used to evaluate allelopathic activity. In this work, crude ethanol extracts of seeds and seed coats caused almost $50 \%$ of inhibition of germination of $L$. sativa seeds. In contrast, extracts of aerial parts of Equisetum giganteum and Nephrolepis exaltata had no effect on L. sativa seeds [12]. Nonpolar partitions ( $n$-hexanic and dichloromethanic) of seed extract of $A$. hypogaea showed the highest capacities of inhibition of germination of L. sativa. The same values were found for equivalent partitions of aqueous leaf extract of Sapindus saponaria, which could also inhibit the germination of L. sativa [13].

In addition to seed germination of $L$. sativa, extracts were evaluated in relation to their effect on seedling growth. Among the organs evaluated, seed extracts showed the lowest $\mathrm{IC}_{50}$ for inhibiting both hypocotyls $(72.98 \mathrm{ppm})$ and rootlets (77.43 ppm) growth. These values were even lower than those reported by other authors for resveratrol $\left(\mathrm{IC}_{50}=90 \mathrm{ppm}\right)$, a constitutive compound of Arachis species, also in relation to inhibition of L. sativa's growth [14].

The concentrations used to determine the plant growth inhibitory activity usually vary in a wide range of high values. Certainly, they are unreasonable when thinking in farming use in the field, considering the possibility of environmental damage and disadvantaging the desired ecological balance. For example, rootlets of L. sativa showed an average length of $5.78 \mathrm{~cm}$ when treated with Cuscuta campestris extracts at a concentration of $100 \mathrm{ppm}$. This value was almost three times higher than that observed with extracts of $A$. hypogaea seeds for the same species and at the a similar concentration (less than $2.00 \mathrm{~cm}$ ) [15]. In the evaluation of coffee fruit extracts (Coffea arabica), the concentration required for the growth inhibition of hypocotyls and rootlets of $L$. sativa to be numerically similar to that found in our work was tenfold higher (1000 ppm) [16]. In a study of allelopathic activity of Terminalia catappa fruit extracts biomonitored by L. sativa, it was demonstrated that the $\mathrm{IC}_{50}$ of the dichloromethanic partition was 4.5 times reduced as compared to crude ethanol extracts [17]. In a paper with subfractions of Cleome arabica, a concentration of $3.000 \mathrm{ppm}$ was necessary to inhibit $50 \%$ of L. sativa growth [18]. This concentration was much higher than that used for inhibiting $50 \%$ of the same species with the dichloromethanic partition (19.70 ppm) in the present study. Thus, the $\mathrm{IC}_{50}$ values found for A. hypogaea $(77.43 \mathrm{ppm}$ and $19.70 \mathrm{ppm}$ for the crude extract and the dichloromethanic partition, resp.) for inhibiting growth of rootlets provide indications of the quality of the material studied to obtain substances with potential herbicide activity. 
(I) Average growth of hypocotyls
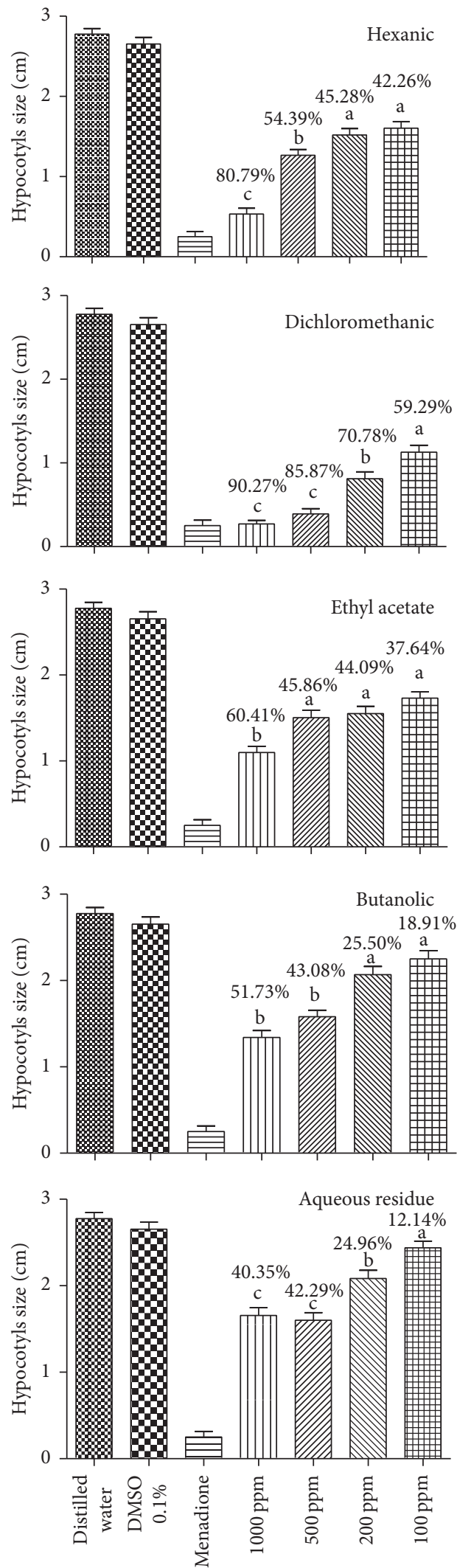

(II) Average growth of rootlets
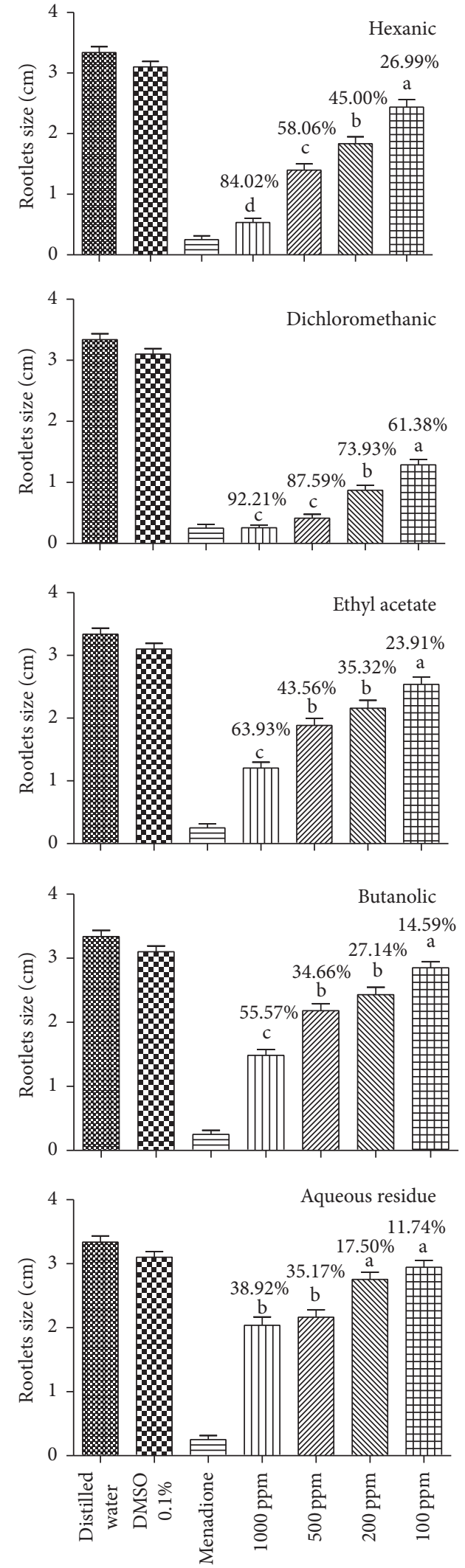

FIGURE 2: Evaluation of allelopathic activity of partitions of seed extracts of Arachis hypogaea (cultivar BR-1) on the growth of hypocotyls and rootlets of $L$. sativa based on the average lengths of each partition and the inhibition percentages are relative to distilled water control. The same letter means no statistically significant difference between the samples in each graphic, according to Tukey's test. 
TABLE 3: Inhibition of L. sativa growth of hypocotyls and rootlets by crude ethanolic extracts of aerial part, root, seed coat, and seed of IAC 886, IAC Caiapó, IAC Tatu ST, IAC 8112, and BR-1 cultivars from Arachis hypogaea.

\begin{tabular}{|c|c|c|c|c|c|c|c|c|}
\hline \multirow{4}{*}{ Cultivar } & \multicolumn{8}{|c|}{ Inhibition in relation to control (\%) } \\
\hline & \multicolumn{8}{|c|}{ Crude extracts } \\
\hline & \multicolumn{2}{|c|}{ Aerial part (96.68 ppm) } & \multicolumn{2}{|c|}{$\operatorname{Root}(367.5 \mathrm{ppm})$} & \multicolumn{2}{|c|}{ Seed coat $(91.46 \mathrm{ppm})$} & \multicolumn{2}{|c|}{ Seed (72.98 ppm) } \\
\hline & Hypoc. & Root. & Hypoc. & Root. & Hypoc. & Root. & Hypoc. & Root. \\
\hline IAC 886 & $52.87^{\mathrm{a}}$ & $58.25^{\mathrm{a}}$ & $36.14^{\mathrm{bc}}$ & $29.07^{\mathrm{b}}$ & $29.75^{\mathrm{b}}$ & $38.52^{\mathrm{bc}}$ & $41.28^{\mathrm{b}}$ & $40.15^{\mathrm{ab}}$ \\
\hline IAC Caiapó & $32.18^{\mathrm{c}}$ & $35.27^{\mathrm{d}}$ & $43.65^{\mathrm{ab}}$ & $33.89^{\mathrm{ab}}$ & $27.52^{\mathrm{b}}$ & $32.97^{\mathrm{c}}$ & $27.98^{c}$ & $26.78^{\mathrm{c}}$ \\
\hline IAC Tatu ST & $40.19^{\mathrm{b}}$ & $38.59^{\mathrm{cd}}$ & $32.13^{c}$ & $29.81^{\mathrm{b}}$ & $30.18^{\mathrm{b}}$ & $40.10^{\mathrm{b}}$ & $39.58^{\mathrm{b}}$ & $33.98^{\mathrm{bc}}$ \\
\hline IAC 8112 & $42.03^{\mathrm{b}}$ & $43.87^{\mathrm{bc}}$ & $35.62^{\mathrm{c}}$ & $28.32^{\mathrm{b}}$ & $41.78^{\mathrm{a}}$ & $45.21^{\mathrm{ab}}$ & $35.52^{\mathrm{bc}}$ & $36.27^{\mathrm{b}}$ \\
\hline BR-1 & $46.81^{\mathrm{ab}}$ & $50.00^{\mathrm{ab}}$ & $50.00^{\mathrm{a}}$ & $37.24^{\mathrm{a}}$ & $44.09^{\mathrm{a}}$ & $50.00^{\mathrm{a}}$ & $50.00^{\mathrm{a}}$ & $48.51^{\mathrm{a}}$ \\
\hline
\end{tabular}

The same letter means no statistically significant difference between the samples in each column.

Hypoc. $=$ hypocotyl; Root. $=$ Rootlet.

TABLE 4: Inhibition of Lactuca sativa seeds germination by partitions of seed extracts of BR-1 cultivar from Arachis hypogaea, at $1000 \mathrm{ppm}$.

\begin{tabular}{lc}
\hline Partitions $(1000 \mathrm{ppm})$ & Inhibition of germination $(\%)$ \\
\hline Hexanic & $57.78^{\mathrm{a}}$ \\
Dichloromethanic & $68.89^{\mathrm{a}}$ \\
Ethyl acetate & $16.67^{\mathrm{b}}$ \\
Butanolic & $16.67^{\mathrm{b}}$ \\
Aqueous residue & $13.33^{\mathrm{b}}$ \\
\hline
\end{tabular}

The same letter means no statistically significant difference between the samples.

TABLE 5: $\mathrm{IC}_{50}$ of partitions of seed ethanolic extract of cultivar BR-1 of $A$. hypogaea on the inhibition of L. sativa growth of hypocotyls and rootlets.

\begin{tabular}{lcc}
\hline $\begin{array}{l}\text { Seed extract partitions of cultivar BR-1 } \\
\text { (Arachis hypogaea) }\end{array}$ & \multicolumn{2}{c}{$\mathrm{IC}_{50}(\mathrm{ppm})$} \\
\hline Hexanic & 93.93 & 216.8 \\
Dichloromethanic & 23.88 & 19.70 \\
Ethyl acetate & 42.95 & 447.6 \\
Butanolic & 361.6 & 976.6 \\
Aqueous residue & 310.7 & 1360.0 \\
\hline
\end{tabular}

TABLE 6: Inhibition of weed plants (Commelina benghalensis and Ipomoea nil) growth of hypocotyls and rootlets by dichloromethanic partition of seed extract of cultivar BR-1 of Arachis hypogaea.

\begin{tabular}{|c|c|c|}
\hline \multirow[t]{2}{*}{ Species } & \multicolumn{2}{|c|}{$\begin{array}{l}\text { Inhibition of seed germination of } \\
\text { weed plants by dichloromethanic } \\
\text { partition }\left(\mathrm{IC}_{50}=19.70 \mathrm{ppm}\right)(\%)\end{array}$} \\
\hline & Hypocotyl & Rootlet \\
\hline Commelina benghalensis & $14.29^{\mathrm{b}}$ & $23.56^{\mathrm{b}}$ \\
\hline Ipomoea nil & $33.78^{\mathrm{a}}$ & $38.11^{\mathrm{a}}$ \\
\hline
\end{tabular}

The same letter means no statistically significant difference between the samples.

The allelopathic activity of certain species is very important to diminish the spread of weeds on crops. Thus, some plant extracts can act as natural herbicides, bringing many benefits to crops. Evaluation of the dichloromethanic partition of ethanolic extract of $A$. hypogaea performed in the present study showed inhibition of growth of weed, similarly to the results reported with extracts of Terminalia catappa fruits [17].

\section{Conclusions}

In conclusion, the results showed that aerial part, root, seed, and seed coat extracts of $A$. hypogaea could inhibit the germination of seeds and the growth of hypocotyls and rootlets of L. sativa. The partitions of ethanolic seed extract in $n$-hexane, dichloromethane, ethyl acetate, butanol, and aqueous residue can also have a positive allelopathic activity. Dichloromethanic partition of ethanolic seed extract is showed to be an environmentally sustainable alternative herbicide for weed management in other large-scale crops.

\section{Conflicts of Interest}

The authors declare no conflicts of interest.

\section{Acknowledgments}

The authors thank FAPERJ (no. E-26/110.125/2013) and CNPq (no. 305265/2014-8) for the financial support and Agronomic Institute of Campinas for the providing of seeds.

\section{References}

[1] R. Jaime-Garcia and P. J. Cotty, "Crop rotation and soil temperature influence the community structure of Aspergillus flavus in soil," Soil Biology \& Biochemistry, vol. 42, no. 10, pp. 1842-1847, 2010.

[2] H. L. Thi, P. Hyuk, P. Y. Ji et al., "Allelopathy in Sorghum bicolor (L.) Moench: a review on environmentally friendly solution for weed control," Research on Crops, vol. 16, no. 4, pp. 657-662, 2015.

[3] M. Asaduzzaman, D. J. Luckett, R. B. Cowley, M. An, J. E. Pratley, and D. Lemerle, "Canola cultivar performance in weedinfested field plots confirms allelopathy ranking from in vitro testing," Biocontrol Science and Technology, vol. 24, no. 12, pp. 1394-1411, 2014. 
[4] C. L. Cantrell, F. E. Dayan, and S. O. Duke, "Natural products as sources for new pesticides," Journal of Natural Products, vol. 75, no. 6, pp. 1231-1242, 2012.

[5] D. T. Khang, L. H. Anh, P. T. Thu Ha et al., "Allelopathic activity of dehulled rice and its allelochemicals on weed germination," International Letters of Natural Sciences, vol. 58, pp. 1-10, 2016.

[6] S. K. Ransing, V. A. Patil, and G. B. Suryavanshi, "Allelopathic effect of different crop seeds on germination of pearl millet," Annals of Plant Physiology, vol. 4, no. 2, pp. 240-242, 1990.

[7] H. Fei and K. Chuihua, "Allelopathic potentials of Arachis hypogaea on crops," Journal of South China Agricultural University, vol. 23, no. 1, pp. 9-12, 2002.

[8] F. Monteles, T. A. Melo, F. Lima Filho, R. Sousa, M. Silva, and I. Serra, "Efeito alelopático dos extratos aquosos de amendoim forrageiro (Arachis pintoi) e da erva-de-touro (Tridax procumbens) sobre a germinação de sementes de tomate (Solanum lycopersicum) e pimentão (Capsicum annum)," Cadernos de Agroecologia, vol. 6, pp. 1-5, 2011.

[9] G. Chiapusio, A. M. Sánchez, M. J. Reigosa, L. E. González, and F. Pellissier, "Do germination indices adequately reflect allelochemical effects on the germination process?" Journal of Chemical Ecology, vol. 23, no. 11, pp. 2445-2453, 1997.

[10] K. Fukuhara and I. Kubo, "Isolation of steroidal glycoalkaloids from Solanum incanum by two countercurrent chromatographic methods," Phytochemistry, vol. 30, no. 2, pp. 685-687, 1991.

[11] X. K. Gao, G. J. Liu, and H. F. Li, "Study on allelopathic effects of Arachis hypogaea extracts on cucumber seeds," Northern Horticulture, vol. 9, pp. 16-18, 2013.

[12] D. M. Franco, L. F. Almeida, and R. Poletto, "Allelopathic potential of Equisetum giganteum L. and Nephrolepis exaltata L. on germination and growth of cucumber and lettuce," Journal of Plant Sciences, vol. 2, no. 5, pp. 237-241, 2014.

[13] P. U. Grisi, S. C. J. Gualtieri, M. A. Ranal, and D. G. de Santana, "Phytotoxic activity of crude aqueous extracts and fractions of young leaves of Sapindus saponaria L. (Sapindaceae)," Acta Botanica Brasilica, vol. 27, no. 1, pp. 62-70, 2013.

[14] P. Fan, K. Hostettmann, and H. Lou, "Allelochemicals of the invasive neophyte Polygonum cuspidatum Sieb. \& Zucc. (Polygonaceae)," Chemoecology, vol. 20, no. 3, pp. 223-227, 2010.

[15] M. R. Othman, S. T. Leong, B. Bakar, K. Awang, and M. S. Annuar, "Allelopathic Potentials of Cuscuta campestris Yuncker Extracts on Germination and Growth of Radish (Raphanus sativus L.) and Lettuce (Lactuca sativa L.)," Journal of Agricultural Science, vol. 4, no. 9, pp. 57-63, 2012.

[16] R. M. G. Silva, J. G. F. Brigatti, V. H. M. Santos, G. F. Mecina, and L. P. Silva, "Allelopathic effect of the peel of coffee fruit," Scientia Horticulturae, vol. 158, pp. 39-44, 2013.

[17] T. D. G. Baratelli, A. C. Candido Gomes, L. A. Wessjohann, R. M. Kuster, and N. K. Simas, "Phytochemical and allelopathic studies of Terminalia catappa L.(Combretaceae)," Biochemical Systematics and Ecology, vol. 41, pp. 119-125, 2012.

[18] A. Ladhari, F. Omezzine, M. DellaGreca, A. Zarrelli, S. Zuppolini, and R. Haouala, "Phytotoxic activity of Cleome arabica L. and its principal discovered active compounds," South African Journal of Botany, vol. 88, pp. 341-351, 2013. 

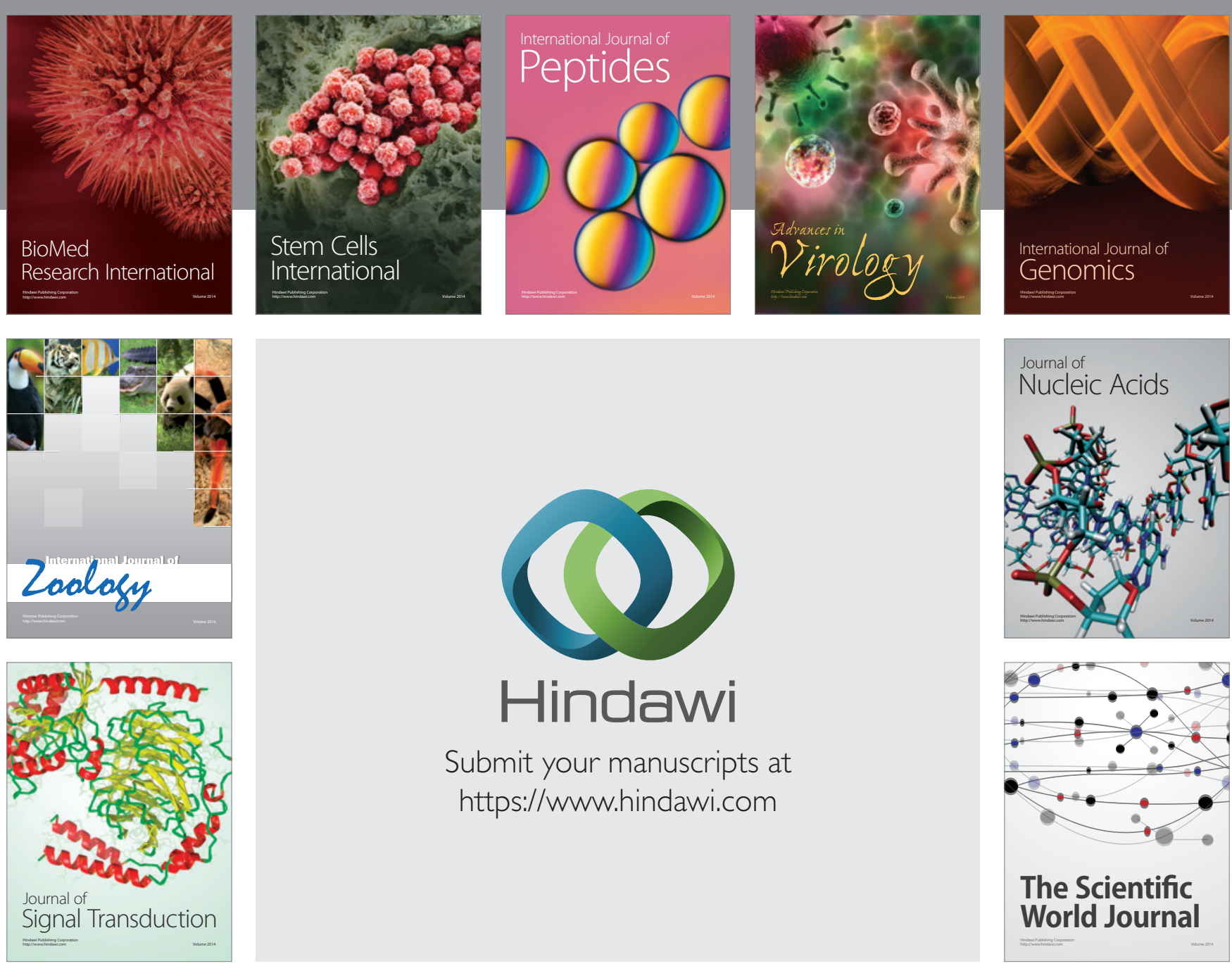

Submit your manuscripts at

https://www.hindawi.com
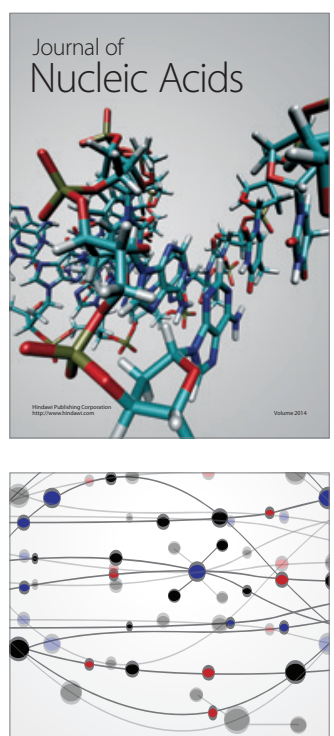

The Scientific World Journal
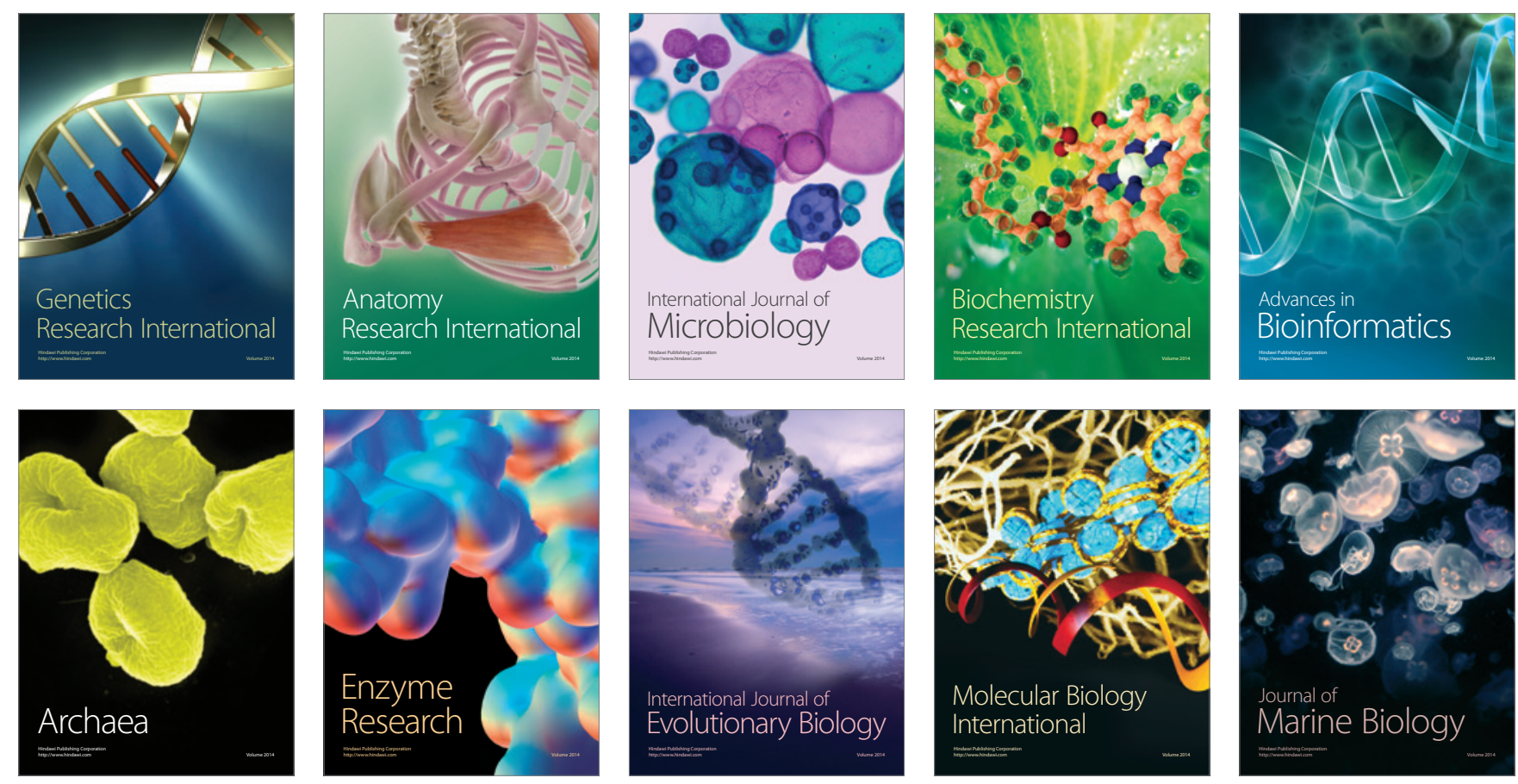